\title{
Studi identifikasi keanekaragaman hayati pada habitat Jalak Lawu, wilayah lereng Gunung Lawu, Kabupaten Magetan
}

\author{
O. P. Astirin ${ }^{1,3^{*}}$, Sugiyarto ${ }^{1}$, S. Nugraha ${ }^{2,3}$ \\ 1 Program Studi Biologi, FMIPA, Universitas Sebelas Maret, Surakarta, Indonesia \\ 2Program Studi Pendidikan Geografi, FKIP, Universitas Sebelas Maret, Surakarta, Indonesia \\ 3Pusat Penelitian Lingkungan Hidup, Universitas Sebelas Maret, Surakarta, Indonesia
}

\begin{abstract}
Abstrak
Jalak Lawu (Turdus sp.) merupakan spesies endemik yang banyak hidup di kawasan Gunung Lawu, Kabupaten Magetan dengan ketinggian $3265 \mathrm{mdpl}$. Populasi burung Jalak Lawu semakin menurun. Pemerintah Kabupaten Magetan menggunakan satwa ini sebagai salah satu ikon pariwisata. Penurunan populasi ini perlu diantisipasi dengan pemahaman atas perilaku, konservasi jenis pakan, maupun upaya untuk melakukan konservasinya. Penelitian dilakukan dengan observasi langsung terhadap burung dan vegetasi sekitarnya. Hasil penelitian menyimpulkan bahwa Jalak Lawu lebih banyak muncul pada sore hari dan berada di pos 2 (ketinggian $700 \mathrm{mdpl}$ ). Tanaman pakan yang tersedia dan terdapat di kawasan studi ada 7 spesies yaitu Manis Rejo (Vaccinium varingiaefolium [Bl.] Miq.), Putat (Planchonia valida [B.] B1), Rubus alpestris Bl., Rubus linaetus Bl., Rubus fraxinifolius Poir, Rubus niveus Thunb dan Rubus rosafolius J.E. Upaya konservasi Jalak Lawu dapat dilakukan secara ex-situ maupun in-situ, tergantung kebijakan yang ditetapkan oleh instansi yang terkait dan berwenang.
\end{abstract}

Kata kunci: Jalak Lawu (Turdus sp.), biodiversitas Gunung Lawu, konservasi burung

\begin{abstract}
.
Jalak Lawu (Turdus sp.) is an endemic species living in a Mount Lawu, Central Java, with a height up to 3265 meters above sea level. However, the population of Jalak Lawu is decreasing. The government of Magetan Regency is tried to protect them and declare it as a tourism mascot. This situation should be anticipated by increasing the knowledge of bird behaviour, bird food conservation, and bird conservation. The study was conducted by direct observation of birds and surrounding vegetation. It was concluded that Jalak Lawu mostly appears on the afternoon at station 2, up to 700 meters above sea level. There are 7 kinds of food that can be eaten by the Jalak Lawu in the conservation area, namely, Manis Rejo (Vaccinium varingiaefolium [Bl.] Miq.), Putat (Planchonia valida [B.] B1), Rubus alpestris BI., Rubus lineatus BI., Rubus fraxinifolius Poir, Rubus niveus Thunb, and Rubus rosafolius J.E. An attempt to conserve the Jalak Lawu can be achieved by ex-situ or in-situ method, depending on the policy from the authority.
\end{abstract}

Keywords: Jalak Lawu (Turdus sp.), Mount Lawu biodiversity, bird conservation

\section{PENDAHULUAN}

Dewasa ini, terdapat tiga isu penting yang saling berkaitan dalam kehidupan yakni ketahanan pangan, keanekaragaman hayati dan perubahan iklim. Dampak dari perubahan iklim seperti banjir, kekeringan dan badai merupakan hal yang perlu diantisipasi oleh sektor pertanian. Ketersediaan pangan penduduk akan bergantung pada ketersediaan sumber daya hayati berupa tumbuh-tumbuhan, hewan dan mikroba. Secara sederhana, keanekaragaman hayati merupakan keanekaragaman tumbuhan atau satwa yang terdapat di suatu daerah tertentu. Indonesia sebagai salah satu negara mega biodiversity di dunia memiliki peranan penting bagi dunia dalam mewujudkan ketahanan pangan, kesejahteraan dan pembangunan berkelanjutan melalui perlindungan aset keanekaragaman hayatinya.

\footnotetext{
${ }^{*}$ Korespondensi Penulis

Email : parama_astirin@yahoo.com
} 
Kabupaten Magetan terletak pada koordinat $7^{\circ} 38^{\prime} 30^{\prime \prime}$ LS dan $111^{\circ} 20^{\prime} 30^{\prime \prime}$ BT, berbatasan dengan Kabupaten Ngawi di sebelah Utara, Kabupaten Madiun di sebelah Timur, Kabupaten Wonogiri dan Ponorogo di sebelah Selatan serta Kabupaten Karanganyar di sebelah barat. Suhu udara berkisar $16-20{ }^{\circ} \mathrm{C}$ di dataran tinggi dan $22-26^{\circ} \mathrm{C}$ di dataran rendah. Curah hujan rata-rata berkisar 2500-3000 mm di dataran tinggi dan berkisar 1300-1600 mm di dataran rendah. Keberagaman topografi yang ada di Kabupaten Magetan tentunya menyimpan keanekaragaman hayati yang khas di tiap-tiap kecamatan. Selain itu, Gunung Lawu yang merupakan bagian dari Kabupaten Magetan dengan ketinggian 3265 mdpl tentunya memiliki keanekaragaman hayati yang banyak. Salah satu hewan endemiknya adalah burung Jalak Lawu (Turdus sp.) yang populasinya semakin menurun. Burung Jalak Gading (Turdus poliocephalus stresemanni Bartels) merupakan burung endemik di kawasan lereng gunung tersebut (Natus 2005; Peterson 2007). Ada pula jenis Jalak lain yang kekurangan pigmen karena faktor genetik sehingga bulunya berwarna putih. Jenis Jalak yang mengalami malformasi pada kelenjar pembentuk pigmen adalah jenis Turdus merula, yang menurut Izquierdo et al. (2018) Jalak ini disebut menderita leucism (albino). Jenis burung Jalak Lawu (Turdus sp.) yang berwarna hitam digunakan sebagai salah satu ikon pariwisata oleh Pemerintah Kabupaten Magetan.

Jalak Lawu merupakan spesies burung endemik yang sering terlihat oleh para pendaki. Jalak Lawu disebut juga sebagai Jalak Gading oleh penduduk sekitar. Burung ini biasanya menjadi teman perjalanan para pendaki di Gunung Lawu, karena perilakunya yang ramah dan jinak. Jalak Lawu akan mengikuti dan menunjukkan jalan ke arah puncak gunung kepada para pendaki atau peziarah. Burung Jalak Lawu ini dianggap keramat, bahkan ada kepercayaan bahwa para pendaki yang diikuti dan ditunjukkan jalan menuju Hargo Dumilah (puncak Gunung Lawu) oleh burung ini adalah para pendaki yang mendapat berkah dari Sunan Lawu (PMPA KOMPOS 2003). Ciri Jalak Lawu adalah memiliki bulu berwarna cokelat, berwarna kuning emas pada bagian dada, berwarna kuning gading pada bagian kaki dan paruh yang berbentuk lancip, serta tampak begitu jinak namun langsung terbang begitu didekati. Gerakan-gerakan dari burung ini relatif sama dengan jenis Jalak yang lain. Makanan utama Jalak Lawu adalah serangga dan buah-buahan.

Kerusakan lingkungan telah menjadi masalah bersama, perubahan alih fungsi lahan, penggundulan hutan dan pencemaran memberikan kontribusi yang sangat besar terhadap kerusakan alam. Kerusakan alam tentunya membuat ketidakseimbangan dalam ekosistem yang berdampak terhadap berkurangnya keanekaragaman hayati. Mengingat sifat endemisitasnya, maka diperlukan upaya pelestariannya melalui berbagai pendekatan. Dengan mengetahui cara konservasi terhadap keanekaragaman hayati yang ada, diharapkan dapat 
mengurangi dampak kerusakan alam. Oleh karena itu, perlu adanya inventarisasi keanekaragaman hayati dan strategi pengelolaannya (konservasi in-situ dan ex-situ) di Kabupaten Magetan. Untuk kepentingan konservasi sumber daya hayati, diperlukan data lingkungan (biotik maupun abiotik) yang menyeluruh. Studi ini bertujuan untuk mengidentifikasi database keanekaragaman hayati spesies dan ekosistem habitat pendukung kehidupan burung Jalak Lawu di lereng Gunung Lawu, Kabupaten Magetan. Prioritas keragaman flora yang dikaji adalah yang dapat berfungsi sebagai tempat bersarang, bereproduksi, sumber pangan, serta sebagai predator/musuh alaminya. Disamping itu juga diharapkan dapat tersusun strategi konservasi Jalak Lawu di Kabupaten Magetan.

\section{METODOLOGI}

Data studi diambil di jalur pendakian Cemoro Sewu Gunung Lawu Kabupaten Magetan. Pengambilan data dilakukan pada 5 pos di sepanjang jalur pendakian. Dalam studi ini ada 3 sub tema studi, yakni sebagai berikut:

a. Pertama, kelimpahan populasi dan tingkah laku burung Jalak Lawu: dipilih satu lokasi yang strategis, yang memungkinkan untuk melakukan pengamatan ke ruang terbuka di sekelilingnya. Sebanyak 4 pengamat duduk/berdiri di posisi tersebut dengan saling membelakangi (menghadap utara, selatan, barat dan timur). Dilakukan penghitungan jumlah burung Jalak Lawu yang berada di masing-masing sektor pengamatan selama satu jam; mengamati tingkah laku burung Jalak Lawu, misal sedang makan, istirahat, bersarang, dll. Hasil penghitungan burung Jalak Lawu dari keempat pengamat dijumlahkan untuk mendapatkan total populasi. Pengamatan dilakukan pada 3 waktu berbeda, yaitu pagi (06.00-08.00 WIB), siang (11.00-13.00 WIB) dan sore (15.00-17.00 WIB).

b. Kedua, jenis-jenis tumbuhan sumber pakan dan bersarang burung Jalak Lawu: dilakukan penggalian informasi tentang jenis-jenis tumbuhan yang digunakan sebagai sarang maupun sumber pakan burung Jalak Lawu berdasarkan pengamatan langsung maupun informasi dari warga setempat. Dilakukan koleksi, identifikasi, karakterisasi serta estimasi populasinya pada masing-masing pos pengamatan. Dilakukan pengamatan tingkah laku burung yang diamati.

c. Ketiga, struktur dan komposisi vegetasi di habitat burung Jalak Lawu: dipilih 4 lokasi/titik sampling yang representatif untuk pos pengamatan tersebut serta terjangkau secara teknis kemudian. Dibuat transek kuadrat seluas $100 \mathrm{~m}^{2}$ untuk pengamatan vegetasi. Pengamatan vegetasi pakan mengacu pada metode Gauthier et al. (2010) yang menetapkan spesies pakan yang didasarkan pada tiga kriteria. Dua kriteria utama yang terkait 
dengan kelangkaan spesies adalah (a) ukuran kisaran kecil dan dengan demikian tanggung jawab regional dan (b) jumlah populasi yang rendah dan dengan demikian kelangkaan lokal, sedangkan kriteria ketiga adalah (c) kerentanan habitat untuk membedakan spesies yang saat ini terancam oleh kegiatan manusia.

\section{HASIL DAN PEMBAHASAN}

Gunung Lawu yang dikenal pula dengan nama Wukir Mahendra merupakan pegunungan vulkanik tua yang secara geografis terletak pada posisi $7^{\circ} 30^{\prime} \mathrm{LS}$ dan $111^{\circ} 15^{\prime} \mathrm{BT}$ dengan luasan areal sekitar 15 ribu hektar. Berdasarkan keterangan warga masyarakat Plaosan, Jalak Lawu sering muncul dan memandu para pendaki gunung. Terdapat dua teknik dalam mengamati keberadaan Jalak Lawu ini yakni dengan melihat arah terbangnya (jika cuaca cerah) dan dengan mencermati suara pekikannya (jika cuaca berkabut). Burung Jalak Lawu yang hidup di Gunung Lawu ini belum diketahui secara pasti jumlahnya. Menurut warga sekitar, saat ini Jalak Lawu sudah jarang dijumpai di kawasan setempat. Kualitas habitat yang menurun akibat dari aktivitas manusia, rendahnya kesadaran masyarakat, serta lemahnya pengamanan, pengawasan dan penerapan sanksi hukum menjadi faktor-faktor penyebab terjadinya kondisi penurunan populasi burung ini.

Gambaran rute pendakian lewat Dusun Cemoro Sewu dimulai dari start pendakian di posko Cemoro Sewu s/d pos 1 yang memiliki kemiringan berkisar 30-40 derajat, sedikit demi sedikit menanjak, banyak kelokan, serta jalan setapak yang berupa makadam sepanjang $\pm 500 \mathrm{~m}$. Selanjutnya, antara pos 1 dengan pos 2 kurang lebih terletak pada ketinggian 2000 mdpl, dengan medan yang semakin terjal dan kemiringan sekitar 40-50 derajat. Semakin ke atas sejauh 1500 m yakni antara pos $2 \mathrm{~s} / \mathrm{d}$ pos 5 , kondisinya benar-benar curam dan terjal dengan kemiringan mencapai 50-80 derajat dan jalan yang berbatu. Selanjutnya, antara leher gunung (pos 5) sampai puncak Hargo Dumilah sejauh $1000 \mathrm{~m}$, medan yang curam sudah tidak tampak, daerah sedikit landai, naik turun dan melingkar mengelilingi puncak.

Kondisi di puncak Gunung Lawu terdapat bukit-bukit kecil seperti Hargo Dumilah dan Cokro Suryo, jurang-jurang kawah Condrodimuko, Cokrosrengenge, Pawon Sewu yang terlihat mengerikan dan terkesan mistis, serta lembah bekas muntahan gunung ratusan ribu tahun lalu yang sudah membeku. Panorama di bagian belahan selatan berupa hutan alam yang berbukit-bukit sampai turun ke lereng bawah. Pada bagian belahan utara berupa lembah-lembah, serta terlihat jelas pula bukit pasar Dieng dan Selo Pundutan. Total jarak tempuh dari Dusun Cemoro Sewu hingga Puncak Hargo Dumilah sekitar $7 \mathrm{~km}$, yaitu posko pemberangkatan-pos 1 sepanjang 1,99 km, pos 1-pos 
2 sepanjang 2,25 km, pos 2-pos 3 sepanjang $0,70 \mathrm{~km}$, pos 3-pos 4 sepanjang $1,75 \mathrm{~km}$ dan pos terakhir yaitu pos 4, pos 5 hingga ke puncak sepanjang $0,30 \mathrm{~km}$.

Tabel 1 . Data individu Jalak Lawu.

\begin{tabular}{cccccc}
\hline \multirow{2}{*}{ Pos } & & Waktu & \multirow{2}{*}{ Total (ekor) } \\
\cline { 2 - 4 } & Pagi & Siang & Sore & \\
\hline 1 & 5 & - & 24 & 29 \\
2 & 14 & 7 & 23 & 44 \\
3 & 10 & 6 & 15 & 31 \\
4 & 12 & 5 & 7 & 24 \\
5 & - & 4 & - & 4 \\
\hline
\end{tabular}

Burung Jalak Lawu terus mengikuti pendakian tim selama hampir sepanjang jalan pendakian (Tabel 1). Kegiatan burung yang terlihat adalah mencari makan di pohon, mencari makan di tanah dan bertengger.

\subsection{Jenis tumbuhan pakan dan bersarang}

Ditemukan 7 jenis tumbuhan sebagai sumber makanan Jalak Lawu yaitu Manis Rejo (Vaccinium varingiaefolium [Bl.] Miq.), Putat (Planchonia valida [B.] B1), Rubus alpestris Bl., Rubus linaetus Bl., Rubus fraxinifolius Poir., Rubus niveus Thunb dan Rubus rosafolius J.E. Bagian tumbuhan yang dimakan adalah buah yang sudah masak. Selain tumbuhan tersebut juga ditemukan aktivitas burung Jalak Lawu yang sedang memakan sisa makanan pendaki seperti mi instan dan nasi, namun belum terdokumentasi. Jalak Lawu yang dijumpai di pos, 1, pos 2, pos 3, pos 4 dan pos 5 dapat ditunjukkan pada Gambar 1. 

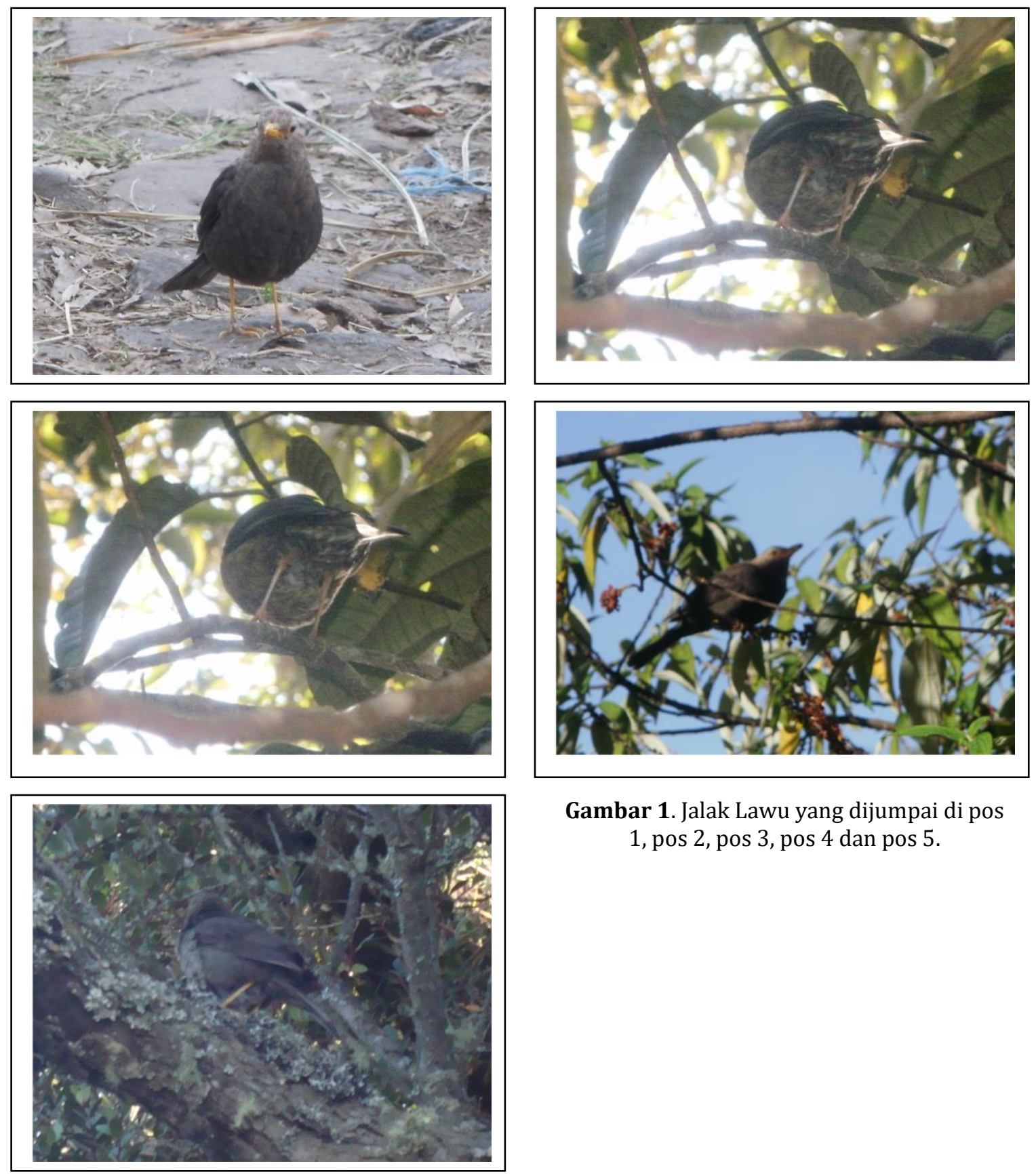

Gambar 1. Jalak Lawu yang dijumpai di pos 1 , pos 2, pos 3, pos 4 dan pos 5 .

\subsection{Struktur komposisi vegetasi}

Pada elevasi 2100-2200 mdpl terdapat lahan pertanian di sebelah kanan dan kiri jalur pengamatan. Pos 2 merupakan batas lahan pertanian di jalur 
Cemoro Sewu. Setelah pos 2, vegetasi terdiri dari struktur hutan yang rendah dengan pohon cemara gunung yang tinggi. Dari keseluruhan pos pengamatan ditemukan 32 jenis tumbuhan dari golongan pohon (12 spesies), perdu (15 spesies), semak dan herba ( 5 spesies) dan 7 diantaranya sebagai sumber pakan Jalak Lawu (Vaccinium varingiaefolium [Bl.] Miq., Planchonia valida [B.] B1., Rubus alpestris $\mathrm{Bl}$., Rubus linaetus $\mathrm{Bl}$., Rubus fraxinifolius Poir., Rubus niveus Thunb., Rubus rosafolius J.E.), sebagaimana yang ditunjukkan pada Gambar 2 dan status kelangkaannya sebagaimana ditunjukkan pada Tabel 2. Bagian tumbuhan yang dimakan adalah buah yang sudah masak. Aktivitas makan lebih banyak ditemui pada siang dan sore hari meskipun banyak dijumpai burung pada pagi hari.

Jalak Lawu ternyata menyukai jenis buah-buahan yang memiliki warna merah dan ungu. Pernyataan yang sama disampaikan oleh Murray et al. (1993) dan Johansen et al. (2014) bahwa burung lebih menyukai buah dan biji-bijian. Hasil penelitian Duan et al. (2014) juga menunjukkan bahwa burung yang ditangkap liar lebih menyukai buah alami berdaging hitam dan merah, sedangkan burung peliharaan yang dibesarkan dalam sangkar lebih memilih buah berdaging hitam daripada buah berdaging alami merah dan yang berwarna lain. Hasil penelitian Stostad et al. (2017) menunjukkan bahwa burung lebih suka jenis pakan kaya protein dan energi, namun apabila jenis ini tidak dijumpai maka burung juga akan memakan pakan artifisial seperti roti dan bahan makanan yang kaya akan karbohidrat. Burung Jalak Lawu juga memakan beberapa jenis serangga dengan cara mematuk-matuk permukaan tanah untuk mencari serangga.

Jenis burung Jalak memang memiliki jenis makanan yang beragam mulai dari jenis buah-buahan kecil, serangga dan biji-bijian. Jenis makanan tersebut dikonsumsi untuk memenuhi banyaknya jenis nutrisi. Namun untuk Jalak Lawu terlihat lebih banyak memakan jenis buah seperti manis rejo (Vaccinium varingiaefolium [Bl.] Miq.) dan jenis berri hutan. Selain digunakan sebagai sumber pakan, beberapa jenis pohon digunakan pula sebagai tempat bersarang.

Pola bersarang burung Jalak Lawu cenderung lebih menyukai tempat yang tinggi. Posisi sarang terletak di percabangan yang banyak agar terlindungi. Jenis tumbuhan yang dipakai dalam membuat sarang lebih banyak dari rumputrumputan, namun di sela-sela terdapat ranting dan daun kering. Spesies Vaccinium varingiaefolium, Albizia lopantha dan Anaphalis javanica adalah jenisjenis pohon yang dipilih Jalak Lawu untuk bersarang. Ketinggian sarang dari tanah berkisar 0,2-7 m. Sarang justru banyak ditemukan tidak jauh dari jalur dan pos pendakian dimana banyak aktivitas manusia (Budiharjo 2005).

Buah Debregaesia longifolia juga dapat ditemukan cukup melimpah di beberapa tempat sepanjang pos 3 dan 4, namun tumbuhan ini tidak berbuah 
sepanjang tahun. Produksi buah yang cukup melimpah dijumpai pada bulan September dan Desember, sedangkan tumbuhan ini tidak dalam kondisi berbuah pada bulan Maret dan April. Menurut Sasidharan (2004), D. Longifolia adalah perdu, tingginya dapat mencapai 3-5 m, merupakan tumbuhan evergreen dan penyusun lapisan kedua hutan pegunungan.
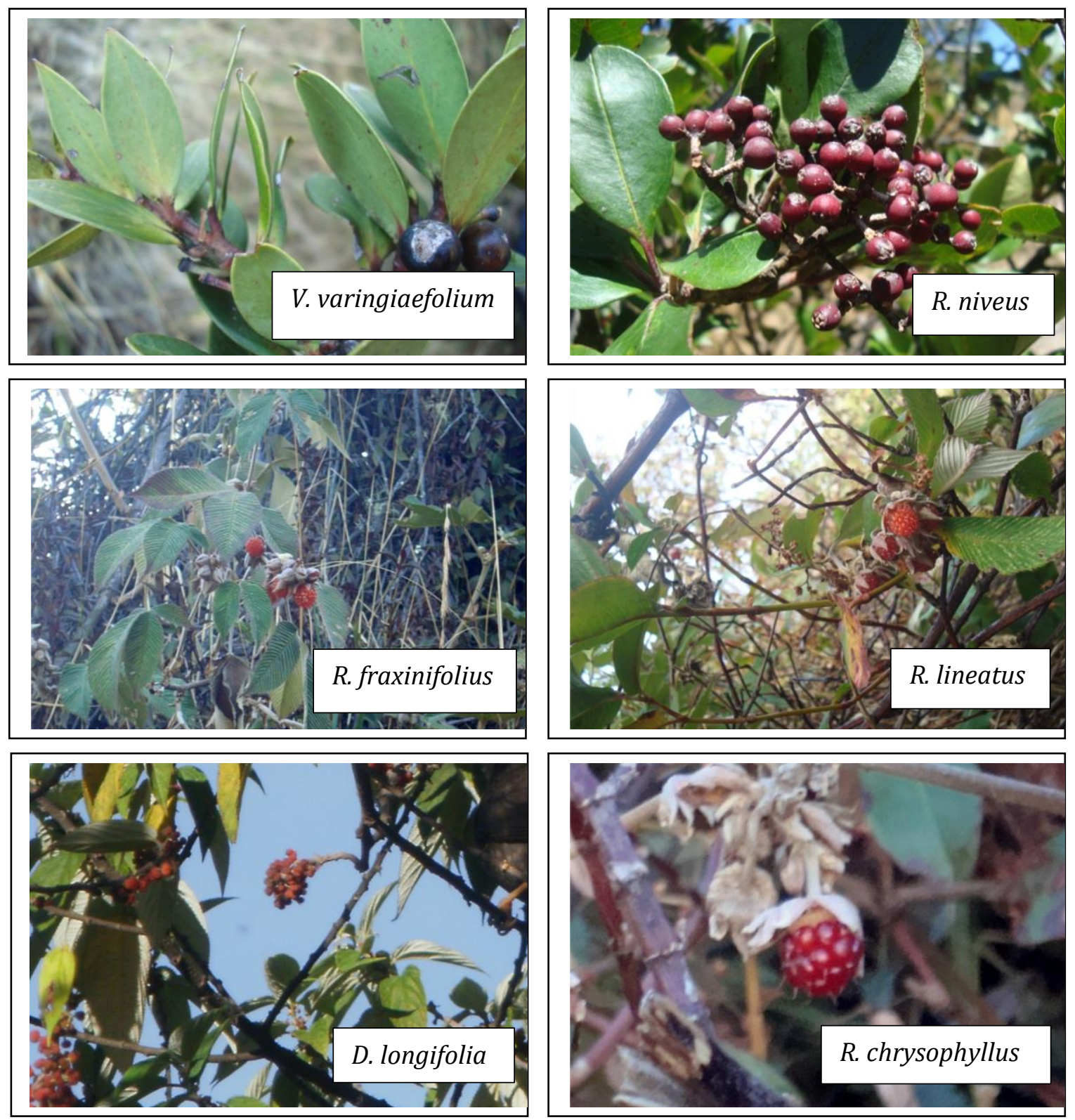

Gambar 2. Jenis tumbuhan sebagai sumber pakan Jalak lawu yang dijumpai di pos 1, pos 2, pos 3, pos 4 dan pos 5 . 
Tabel 2. Vegetasi yang teridentifikasi sebagai sumber pakan dari Jalak Lawu.

\begin{tabular}{|c|c|c|c|c|c|}
\hline No. & Nama Ilmiah & $\begin{array}{l}\text { Nama Lokal/ } \\
\text { Nama Umum }\end{array}$ & $\begin{array}{c}\text { Status } \\
\text { Konservasi } \\
\text { IUCN1) }\end{array}$ & $\begin{array}{c}\text { Status Perlindungan } \\
\text { (PP Nomor } 7 \text { Tahun } \\
\text { 19992) dan } \\
\text { PerMenLHK Nomor } \\
\text { P.92 Tahun 20183)) }\end{array}$ & $\begin{array}{l}\text { Konvensi } \\
\text { Perdagangan } \\
\text { Appendix } \\
\text { CITES } 4 \text { ) }\end{array}$ \\
\hline 1. & $\begin{array}{l}\text { Vaccinium } \\
\text { varingiaefolium [Bl.] } \\
\text { Miq. }\end{array}$ & Manis rejo & LC & - & - \\
\hline 2. & $\begin{array}{l}\text { Planchonia valida [B.] } \\
\text { B1. }\end{array}$ & Putat & LC & - & - \\
\hline 3. & Rubus alpestris $\mathrm{Bl}$. & Berri hutan & - & - & - \\
\hline 4. & Rubus linaetus $\mathrm{Bl}$. & Berri hutan & - & - & - \\
\hline 5. & Rubus fraxinifolius Poir. & Berri hutan & - & - & - \\
\hline 6. & Rubus niveus Thunb. & Berri hutan & - & - & - \\
\hline 7. & Rubus rosafolius J.E & Berri hutan & & & \\
\hline
\end{tabular}

Keterangan:

Status Konservasi menurut IUCN Red List:

DD : Data Deficient (Informasi Kurang)

LC : Least Concern (Beresiko Rendah)

NT : Near Threatened (Hampir Terancam)

VU : Vulnerable (Rentan)

EN : Endangered (Genting atau Terancam)

CR : Critically Endangered (Kritis)

EX : Extinction (Punah)

- $\quad$ : Status Belum ada di IUCN Red List

Status Konvensi Perdagangan Internasional Tumbuhan dan Satwa Liar Spesies Terancam menurut CITES:

Appendix I (App I) : Daftar seluruh spesies tumbuhan dan satwa liar yang dilarang dalam segala bentuk perdagangan internasional.

Appendix II (App II) : : Daftar spesies yang tidak terancam kepunahan, tetapi mungkin terancam punah bila perdagangan terus berlanjut tanpa adanya pengaturan.

Appendix III (App III) : : Daftar spesies tumbuhan dan satwa liar yang dilindungi di negara tertentu dalam batasbatas kawasan habitatnya, serta suatu saat peringkatnya bisa dinaikkan ke dalam Apendiks II atau Apendiks I.

Sumber :

1) The IUCN Red List of Threatened Species (2018-2)

2) Lampiran PP Nomor 7 Tahun 1999 tentang Pengawetan Jenis Tumbuhan dan Satwa

3) PerMenLHK Nomor P.92 Tahun 2018 tentang Perubahan Atas PerMenLHK Nomor P.20 Tahun 2018 tentang Jenis Tumbuhan dan Satwa yang Dilindungi

4) Species+/CITES Checklist (2018)

Jenis vegetasi yang menjadi sumber pakan Jalak Lawu bukan merupakan tumbuhan langka dan dilindungi, sesuai PP Nomor 7 Tahun 1999 tentang Pengawetan Jenis Tumbuhan dan Satwa di Indonesia, dan sesuai PerMenLHK Nomor P.92 Tahun 2018 tentang Perubahan Atas PerMenLHK Nomor P.20 Tahun 2018 tentang Jenis Tumbuhan dan Satwa yang dilindungi. Berdasarkan Status Konvensi Perdagangan Internasional Tumbuhan dan Satwa Liar (Appendix CITES) diketahui tidak terdapat vegetasi yang terancam kepunahan.

Vegetasi pohon diperhitungkan dan diamati kemanfaatannya untuk burung Jalak Lawu. Berbagai jenis tanaman rimba seperti cemara, puspa, kipres dan Tristania spp., kemudian empon-empon seperti kunyit, laos, jahe dan bungabunga berwarna kuning dan merah yang berbaur dengan rerumputan di bawah pohon-pohon, banyak dijumpai di daerah kaki Gunung Lawu yang sebagian 
besar merupakan hutan lindung. Jenis pohon Acasia decurent, Mlandingan gunung dan sebagian Tristania spp. banyak juga dijumpai di daerah perut Gunung Lawu (Tabel 3). Pada wilayah perut gunung ini pepohonan amat lebat dengan sinar matahari yang tidak sepenuhnya mencapai tanah, sehingga wilayah pos 4 dan pos 5 cenderung redup dan dingin.

Tabel 3. Analisis vegetasi pohon.

\begin{tabular}{cccc}
\hline Pos & Jumlah Spesies & Jumlah Individu & Elevasi (mdpl) \\
\hline Pos 1 & 6 & 26 & 2037 \\
Pos 2 & 3 & 10 & 2204 \\
Pos 3 & 3 & 26 & 2500 \\
Pos 4 & 5 & 54 & 2800 \\
Pos 5 & 5 & 110 & 3265 \\
\hline
\end{tabular}

Pada puncak Gunung Lawu, menghampar luas jenis Acasia decurent dan manis rejo hingga menutup permukaan puncak, serta nyaris tidak ada pohon besar. Di sebelah barat juga tidak tampak tumbuhan, karena berupa tebing gunung yang menjulang. Ketiadaan pohon besar ini membuat sinar matahari langsung dapat menerpa kulit, namun suhu udara di lokasi cenderung dingin.

\subsection{Strategi konservasi Jalak Lawu}

Jenis-jenis burung di Indonesia memiliki nilai ekonomi yang cukup tinggi bila dilihat berdasarkan keunikan dan keragaman morfologis, tingkah laku, suara dan dipandang dari perannya sebagai sumber protein hewani. Hal ini menjadi penyebab tingginya perburuan yang berakibat pada penurunan populasi burung di alam. Akibat eksploitasi hutan dan konversi lahan, kualitas maupun kuantitas habitat burung juga semakin berkurang. Permasalahanpermasalahan tersebut mengganggu kelestarian satwa burung yang akhirnya dapat menyebabkan kelangkaan. Oleh karena itu, tindakan konservasi perlu dilakukan baik secara in-situ (di dalam habitat alaminya) maupun ex-situ (di luar habitat alaminya).

Kegiatan penangkaran burung sebagai salah satu langkah tindakan konservasi memiliki manfaat dalam kepentingan konservasi jenis, peningkatan populasi, pengembangan ekowisata dan sarana edukasi serta riset. Hasil penangkaran dapat dilepasliarkan ke habitat alam sesuai regulasi dan syaratsyarat yang berlaku. Selain itu, sebagian dari hasil penangkaran terutama mulai dari hasil keturunan kedua (F2), dapat dimanfaatkan secara komersial.

Penangkaran burung harus mempertimbangkan kesiapan lingkungan penangkaran, baik lingkungan biologi (habitat hidup burung) maupun lingkungan fisik (kandang/sangkar), yang mana sistem pemeliharaan beserta lingkungannya mengacu pada perilaku dan habitat alami. Kegiatan teknis yang dapat dilakukan yaitu pemilihan bentuk dan ukuran kandang, pengelolaan 
penangkaran (kesehatan, pakan, reproduksi dan sex ratio), penyiapan tumbuhan pelindung dan sumber pakan, serta sistem pencatatan. Kegiatan penangkaran burung didasarkan kepada PP Nomor 7 Tahun 1999 tentang Pengawetan Jenis Tumbuhan dan Satwa, serta PP Nomor 8 Tahun 1999 tentang Pemanfaatan Jenis Tumbuhan dan Satwa Liar. Kegiatan penangkaran dan koleksi sebagaimana diatur dalam PP Nomor 8 Tahun 1999 merupakan bagian dari upaya pemanfaatan dan pendayagunaan jenis flora-fauna liar secara lestari. Namun, jenis-jenis burung yang telah berstatus dilindungi berdasarkan regulasi-regulasi tersebut dan oleh pemerintah daerah dimana habitat jenis burung itu berada, hingga saat ini masih tetap banyak diburu secara liar.

\subsubsection{Konservasi ex-situ}

Konservasi burung secara ex situ melalui pemeliharaan, tidak hanya menitikberatkan pada obyek burung saja, namun harus pula mempertimbangkan kesiapan lingkungan. Tujuannya agar burung-burung yang hendak dipelihara dapat beradaptasi dengan baik dan cepat, terutama untuk jenis-jenis yang membutuhkan lindungan khusus (Setio dan Takandjandji 2006).

Lingkungan pemeliharaan biologi merupakan lingkungan pemeliharaan yang di dalamnya terdapat tumbuhan (baik ditanam maupun tumbuh secara alami) dengan populasi, kerapatan dan arsitektur tajuk yang mendekati habitat alam. Lingkungan biologi akan menciptakan iklim mikro dan suasana teduh, yang pada umumnya disukai oleh burung-burung untuk hidup dan berkembang biak dengan baik.

Lingkungan biologi akan menjadi lebih baik lagi untuk burung dengan adanya jenis tumbuhan yang secara alami digunakan burung sebagai tempat berteduh dan sumber pakan. Hal tersebut juga akan mengundang burungburung liar lainnya untuk datang, sehingga timbul suasana alami yang akan memudahkan adaptasi burung yang akan dipelihara. Tata letak tumbuhan dapat disesuaikan dengan rencana pembangunan kandang/sangkar dan sarana pendukung lainnya (unit karantina, laboratorium, klinik), serta dengan pertimbangan faktor estetika misalnya berfungsi pula sebagai taman. Cahaya matahari diusahakan tidak banyak terhalang oleh padatnya tumbuhan agar Jalak Lawu mampu mengenali lokasi pakan (Hart et al. 2000). Agar tercipta suasana iklim mikro setempat yang teduh (tidak terlalu panas), setidaknya satu individu tumbuhan harus dapat menaungi satu unit kandang/sangkar.

Kandang/sangkar dari burung itu sendiri dan sarana pendukung lainnya merupakan jenis lingkungan pemeliharaan fisik. Persiapan lingkungan biologi dan lingkungan fisik dapat dilakukan secara bersamaan, namun penempatan burung ke dalam kandang/sangkar tidak boleh dilakukan bersamaan apabila lingkungan biologi buatan sebagai habitat hidup burung masih belum siap. 


\subsubsection{Konservasi in-situ}

Penangkaran merupakan kegiatan pengembangbiakan jenis satwa liar dan tumbuhan alam untuk memperbanyak populasi dengan tetap mempertahankan kemurnian jenisnya, sehingga kelestarian dan keberadaannya dapat dipertahankan. Prinsip kebijakan penangkaran jenis satwa liar yang dilakukan di Taman Nasional Bali Barat (TNBB 2010) adalah:

1. Mengupayakan jenis-jenis langka menjadi tidak langka dan pemanfaatannya berasaskan kelestarian.

2. Upaya pelestarian jenis perlu dilakukan di dalam kawasan konservasi dan di luar habitat alaminya. Di luar habitat alami berbentuk penangkaran, baik di kebun binatang maupun lokasi lainnya yang ditangani secara intensif.

3. Peliaran kembali satwa hasil penangkaran ke habitat alaminya adalah untuk meningkatkan populasi sesuai dengan daya dukung habitatnya tanpa mengakibatkan adanya polusi genetik ataupun sifat-sifat yang menyimpang dari aslinya.

Pelaksanaan kegiatan penyelamatan Jalak Lawu dilakukan melalui kerja sama dengan Direktorat Jenderal Perlindungan Hutan dan Pelestarian Alam, Kementerian Lingkungan Hidup dan Kehutanan. Kegiatan penangkaran ini terus dilakukan secara berkelanjutan, sehingga kebutuhan cikal bakal peliaran dalam rangka pemulihan populasi liar Jalak Lawu dan kebutuhan masyarakat peminat penangkar dan peneliti dapat terpenuhi setiap tahunnya. Konservasi in-situ dapat dilakukan pada lokasi yang dibatasi dengan kemungkinan predasi (Slagsvold 1980), maka mekanisme konservasi harus mempertimbangkan spesies predator terhadap kehidupan Jalak Lawu (Thurdus sp.).

Sarang biak disesuaikan dengan kebiasaan Jalak Lawu di alam. Jalak Lawu di kehidupan liarnya, menggunakan media biak pada batang pohon yang berlubang, umumnya jenis pohon digunakan adalah pohon Talok (Grewia koordersiana) dan Walikukun (Shoutenia ovata). Pada kandang penangkaran, media biak tersebut dapat menggunakan bahan kayu berbentuk silindris yang dibuat dengan bagian dalam gerowong, memiliki ukuran diameter $15 \mathrm{~cm}$, panjang/tinggi $50 \mathrm{~cm}$ dan dibuatkan lubang berbentuk lingkaran di salah satu bagian depan dengan diameter 7-8 cm (untuk keluar masuk burung). Media biak ini ditempatkan dengan posisi tegak dan ditempelkan pada dinding atau penyangga. Sangkar sapihan juga diperlukan guna menampung anakan usia sapihan yakni individu anakan mulai usia mandiri (35 hari). Sangkar ini berukuran lebih lebar dari sangkar biak sesuai peruntukannya, setidaknya dapat menampung sebanyak 10 ekor. Sangkar yang ada dan digunakan untuk kepentingan ini yaitu 1 unit ukuran $3 \times 3 \times 2,5 \mathrm{~m}, 1$ unit ukuran $4 \times 3 \times 2,5 \mathrm{~m}$ dan 1 unit berukuran $4 \times 4 \times 2,5 \mathrm{~m}$. 


\section{KESIMPULAN DAN SARAN}

Jalak Lawu lebih banyak muncul pada sore hari dan berada di pos 2 . Tanaman pakan yang tersedia dan terdapat di kawasan studi ada 7 spesies yaitu Vaccinium varingiaefolium [Bl.] Miq., Planchonia valida [B.] B1., Rubus alpestris Bl., Rubus linaetus $\mathrm{Bl}$, Rubus fraxinifolius Poir, Rubus niveus Thunb dan Rubus rosafolius J.E. Upaya konservasi Jalak Lawu dapat dilakukan secara ex-situ maupun in-situ, tergantung kebijakan yang ditetapkan oleh instansi yang terkait dan berwenang.

\section{UCAPAN TERIMAKASIH}

Terima kasih dan penghargaan kepada Badan Lingkungan Hidup, Kabupaten Magetan atas dukungan pendanaan, Mahasiswa Kelompok Studi Biodiversitas PS Biologi FMIPA UNS yang terlibat dalam kegiatan survei dan pelaporan kegiatan: Muhammad Ridwan, Wahyu H., Aru D., Umi F., Wahid F., Risna M.A., Deni Wahyu, N. Hari, Tony S., Hanni T., S Mulyani, Citra A.M, Annisa F.S., Ida R.S., Thiara M., Isnaniar N., Dwi P., Widyatama P.M., Fanji A.G., Aken P.W., Nunung R.H., Imam T., Putri D.A.

\section{DAFTAR PUSTAKA}

Budiharjo A. 2005. Pola reproduksi burung Jalak Gading (Turdus sp) di Gunung Lawu Jawa Tengah. Biodiversitas 6(4):272-275.

Duan Q, Goodale E and Quan RC. 2014. Bird fruit preferences match the frequency of fruit colours in tropical Asia. Scientific Reports 4:5627.

Gauthier P, Debussche M and Thompson JD. 2010. Regional priority setting for rare species based on a method combining three criteria. Journal Biological Conservation 143(6):1501-1509.

Hart NS, Partridge NJC, Cuthill IC and Bennett ATD. 2000. Visual pigments, oil droplets, ocular media and cone photoreceptor distribution in two species of passerine bird: the blue tit (Parus caeruleus L.) and the blackbird (Turdus merula L.). Journal of Comparative Physiology 186(4):375-287.

Izquierdo L, Thomson RL, Aguirre JI, Fernández AD, Faivre B, Figuerola J and Ibáñez-Álamo JD. 2018. Factors associated with leucism in the common blackbird (Turdus merula). Willey Journal of Avian (on proggress publication), cite this article as doi: [10.1111/jav.01778].

Johansen SM, Horn DJ and Wilcoxen TE. 2014. Factors influencing seed species selection by wild birds at feeders. The Wilson Journal of Ornithology 126(2):374-381. 
Murray KG, Murray KW, Cromie EA, Miror M and Meyers E. 1993. The influence of seed packaging and fruit color on feeding preferences of American robins. Plant Ecology 107:217-226.

Natus IR. 2005. Biodiversity and endemic centres of Indonesian terrestrial vertebrates [Dissertation]. Department of VI (Geography/EarthScience), University of Trier. Trier.

PerMenLHK (Peraturan Menteri Lingkungan Hidup dan Kehutanan) Nomor P.92 Tahun 2018 tentang perubahan atas PerMenLHK Nomor P.20 Tahun 2018 tentang jenis tumbuhan dan satwa yang dilindungi.

Peterson AT. 2007. Geographic variation in size and coloration in the Turdus poliocephalus Complex: a first review of species limits. Scientific Papers Natural History Museum 40:1-17.

PP (Peraturan Pemerintah) Nomor 7 Tahun 1999 tentang pengawetan jenis tumbuhan dan satwa.

PP (Peraturan Pemerintah) Nomor 8 Tahun 1999 tentang pemanfaatan jenis tumbuhan dan satwa liar.

[PMPA KOMPOS] Perhimpunan Mahasiswa Pecinta Alam KOMPOS. 2003. Laporan ekspedisi lawu I dan II. Seminar Nasional Lawu. PMPA KOMPOS, Fakultas Pertanian UNS. Surakarta.

Sasidharan N. 2004. Biodiversity documentation for kerala, part 6: flowering plants. Kerala Forest Research Institute. Kerala.

Setio P dan Takandjandji M. 2006. Konservasi ex situ burung endemik langka melalui penangkaran [Prosiding]. Prosiding Ekspose Hasil-Hasil Penelitian: Konservasi dan Rehabilitasi Sumberdaya Hutan. Padang.

Slagsvold T. 1980. Habitat selection in birds: on the presence of other bird species with special regard to Turdus pilaris. Journal of Animal Ecology 49(2):523-536.

Stostad HN, Aldwinckle P, Allan A and Arnold KE. 2017. Foraging on humanderived foods by urban bird species. Journal Bird Study 64(2):178-186.

[TNBB] Taman Nasional Bali Barat. 2010. Pengelolaan penangkaran Jalak bali (Leucopsar rothscildi) di Taman Nasional Bali Barat [internet]. Tersedia di: http://www.tnbalibarat.com. 